\title{
STRATEGI PEMERINTAH KOTA MALANG DALAM MENINGKATKAN KUALITAS PELAYANAN PUBLIK BERBASIS KONSEP SMART CITY
}

\author{
Alfi Haris Wanto \\ Program Studi Administrasi Publik Fakultas Ilmu Administrasi, Universitas Brawijaya, e-mail: alfi@ub.ac.id
}

\begin{abstract}
Abstrak
Lahirnya konsep smart city tumbuh seiring semakin majunya perkembangan teknologi informasi yang merambah hampir seluruh kalangan, tua muda, kaya miskin, desa kota. Masyarakat semakin mudah dan cepat melakukan komunikasi, mendapatkan informasi yang dibutuhkan, serta melakukan pekerjaan lain dengan lebih mudah, cepat, dan ringkas. Metode penelitian ini menggunakan pendekatan kualitatif dengan jenis penelitian deskriptif. Sumber data yang dipergunakan antara lain adalah Informan, Peristiwa, dan Teknik Pengumpulan Data menggunakan wawancara, observasi dan dokumentasi. Instrumen Penelitian dalam penelitian ini menggunakan peneliti sendiri, pedoman wawancara dan perangkat penunjang seperti buku catatan, alat perekam, dan kamera. Model analisis data yang digunakan peneliti adalah model interaktif Miles, Huberman, dan Saldana (2014: 12-14) meliputi Kondensasi data (data condensation), Penyajian Data (data display) dan Penarikan Kesimpulan (Conclusions drawing). Hasil penelitian ini adalah Pemerintah Kota Malang melakukan beberapa strategi dalam meningkatan kualitas pelayanan publik berbasis konsep smart city antara lain dengan beberapa strategi. Yaitu: Strategi membangun (political environment) yang mendukung terselenggaranya tata kelola pemerintah kota Malang yang lebih melayani. Membangun lingkungan politik, Strategi membangun teknologi yang mendukung terselenggaranya proses pelayanan publik yang berebasis pada perkembangan ilmu pengetahuan dan teknologi yang kini mengalami perkembangan yang sangat pesat. Strategi menyiapakan dukungan anggaran untuk terselenggaranya program tersebut. Strategi partisipasi seluruh stakeholders dalam mendukung terlaksananya program tersebut. Stakeholders di sini bisa berasal dari masyarakat, maupun dunia usaha (private sector), tanpa partisipasi dari seluruh stakeholders tersebut kebijakan yang bagus sekalipun akan terasa kurang berdampak pada perubahan positif yang merupakan dampak (outcome) dari sebuah kebijakan yang dihasilkan oleh (policy maker). Saran dari riset ini adalah pemerintah perlu menyiapkan strategi dalam upaya memastikan program ini terus bisa berjalan dengan baik (sustainable).
\end{abstract}

Kata Kunci: smart city, pelayanan publik, electronic government

\begin{abstract}
The concept of smart city grew as the progress of the development of information technology that penetrated almost all circles, young, rich, poor, urban village. Communities make it easier and faster to communicate, get the information they need, and do other jobs more easily, quickly, and succinctly. This research method using qualitative approach with descriptive research type. Data sources used include Informants, Events, and Data Collection Techniques using interviews, observation and documentation. Instruments The research in this study uses the researchers themselves, interview guides and supporting tools such as notebooks, recorders, and cameras. The data analysis model used by the researcher is interactive model Miles, Huberman, and Saldana (2014: 12-14) including data condensation, Data Presentation (Data display) and Conclusions drawing. The results of this study is the Government of Malang City do some strategies in improving the quality of public services based on the concept of smart city, by several strategies. Namely: Strategy to build (political environment) that supports the implementation of governance of Malang city government more serve. Building a political environment, Strategy to build technology that supports the implementation of public service process based on the development of science and technology which is now experiencing rapid growth. Strategy to prepare budget support for the implementation of the program. Strategy of participation of all stakeholders in supporting the implementation of the program. Stakeholders here can come from the community, as well as the private sector, without the participation of all stakeholders, building good political will for the positive changes that are the outcomes of a policy generated by the policy maker. Suggestions from this research is that the government needs to prepare a strategy in an effort to ensure the program continues to run well (sustainable).
\end{abstract}

Keywords: smart city, public service, electronic government. 


\section{PENDAHULUAN}

Smart city merupakan sebuah konsep kota cerdas yang dapat membantu masyarakat dalam mengelola sumber daya yang ada dengan efisien dan memberikan informasi yang tepat kepada masyarakat atau lembaga dalam melakukan kegiatannya atau pun mengantisipasi kejadian yang tak terduga sebelumnya.

Lahirnya konsep smart city tumbuh seiring semakin majunya perkembangan teknologi informasi yang merambah hampir seluruh kalangan, tua muda, kaya miskin, desa kota. Masyarakat semakin mudah dan cepat melakukan komunikasi, mendapatkan informasi yang dibutuhkan, serta melakukan pekerjaan lain dengan lebih mudah, cepat, dan ringkas.

Kota Malang sebagai kota terpesat ke dua di jawatimur setelah surabaya sudah seharusnya menyiapkan diri untuk menjadi sebuah kota yang memberikan pelayanan publik berbasis perkembangan teknologi infomrasi mutakhir kepada warganya. Karena Malang sebagai salah satu kota pendidikan dengan jumlah mahasiswa terbanyak di Indonesia, maka Kota Malang harus melihat peluang ini untuk memberikan yang terbaik kepada warganya.

Banyaknya lembaga pendidikan yang bereputasi nasional dan internasional seharusnya menjadikan Malang sebagai kota yang adaptif dengan perkembangan zaman, terbuka terhadap ilmu pengetahuan dan teknologi namun tetap harus memiliki prinsip nilai luhur bangsa dan agama yang tetap harus dipegang teguh.

Undang-Undang No. 23 Tahun 2014 Tentang Pemerintah Daerah yang terdapat dalam pasal 1 angka 2 yang berbunyi

"Pemerintahan Daerah adalah penyelenggaraan urusan pemerintahan oleh pemerintah daerah dan dewan perwakilan rakyat daerah menurut asas otonomi dan tugas pembantuan dengan prinsip otonomi seluas-luasnya dalam sistem dan prinsip Negara Kesatuan Republik Indonesia sebagaimana dimaksud dalam Undang-Undang Dasar Negara Republik Indonesia Tahun 1945."

Untuk mencapai dari ketentuan Undang-Undang No. 23 Tahun 2014 tentang Pemerintah Daerah tersebut Pemerintah Daerah terus berupaya dalam optimalisasi kekayaan daerahnya untuk meningkatkan kualitas hidup yang lebih baik. Semakin strategis dan dinamis daerah tersebut maka akan membawa dampak yang lebih baik dalam pembangunannya. Tentunya daerah tersebut tidak akan bisa mengoptimalkan kekayaan daerahnya tanpa dorongan dari sumber daya manusia yang handal dalam mengelolanya.

Berdasarkan dari uraian di atas maka rumusan masalah pada penelitian ini anatara lain adalah bagaimana strategi pemerintah kota malang dalam meningkatkan pelayanan publik berbasis konsep smart city?

\section{METODE}

\section{Jenis Penelitian}

Jenis penelitian yang digunakan dalam penelitian ini termasuk jenis penelitian deskriptif dengan pendekatan kualitatif. Karena, peneliti melakukan pengamatan secara langsung di lapangan, untuk melihat secara langsung realitas yang terjadi di lapangan. Menurut Sugiyono (2008: 1) "Metode penelitian kualitatif merupakan metode penelitian yang digunakan untuk meneliti pada kondisi obyek yang alamiah". Alasan pemilihan pendekatan kualitatif ini dikarenakan:

1. Metode kualitatif ini menyajikan secara langsung hakekat hubungan antara peneliti dengan responden.

2. Metode kualitatif ini lebih peka dan lebih dapat menyesuaikan diri dengan banyak penajamanpenajaman, pengaruh bersama dan terhadap pola-pola nilai yang dihadapi.

3. Metode kualitatif lebih mudah menyesuaikan apabila nantinya berhadapan dengan kenyataan ganda.

Melihat alasan-alasan tersebut dapat ditarik kesimpulan bahwa pendekatan kualitatif dengan jenis penelitian deskriptif diharapkan mampu melihat melihat proses yang dilakukan, dengan hasil memperoleh penjelasan dan pengertian yang mendalam dan menyeluruh tentang konsep smart city di Kota Malang.

\section{Fokus Penelitian}

Penetapan fokus penelitian dimaksudkan untuk menentukan pusat penelitian serta membatasi objek kajian dalam penelitian. Penentuan fokus dalam dalam penelitian kualitatif didasarkan pada tingkat kebaruan informasi yang akan diperoleh dari situasi sosial di lapangan. Penelitian ini menggunakan model implementasi kebijakan Merille S. Grindle dalam (Subarsono, 2012: 9394), karena dari model Grindle terletak pada pemahaman yang komprehensif akan konteks kebijakan, khususnya yang menyangkut dengan implementor, penerima implementasi, dan arena konflik yang mungkin terjadi diantara para aktor implementasi, serta kondisi-kondisi sumber daya implementasi yang diperlukan.

1. Strategi pemerintah Kota Malang dalam meningkatkan pelayan publik berbasis konsep Smart City.
a. Strategi Pembangunan Konsep (Blue Print)
b. Strategi Penyiapan Sumber Daya Aparatur Pendukung
c. Strategi Pembangunan Karakter (Budaya)

2. Faktor Pendukung dan Penghambat
a. Faktor Pendukung 


\section{b. Faktor Penghambat}

\section{Sumber Data}

Sumber data merupakan faktor penting yang menjadi pertimbangan dalam menentukan metode pengumpulan data. Sedangkan data-data tersebut harus digali dan diperoleh dari berbagai sumber yang berkaitan dengan penelitian ini adalah:

1. Informan

Data dapat diperoleh langsung dari sumber asli sehubungan dengan obyek yang diteliti dengan cara melakukan wawancara. Adapun informan kunci dalam penelitian ini antara lain adalah pihak pemerintah, masyarakat, dan swasta.

\section{Peristiwa}

Data atau Informasi yang didapat diperoleh melalui pengamatan terhadap peristiwa atau aktivitas yang berkaitan dengan permasalahan penelitian. Dari peristiwa atau kejadian ini, peneliti bisa mengetahui proses itu terjadi karena peneliti mengamati secara langsung. Dengan mengamati peristiwa atau aktivitas tersebut peneliti dapat melakukan cross check terhadap informasi verbal yang diberikan oleh subjek yang diteliti..

\section{Dokumen}

Dokumen merupakan sumber data yang berasal dari bahan-bahan tertulis, dokumen serta arsip yang tertulis dan memiliki relevansi dengan fokus penelitian.Dokumen ini berkaitan dengan fokus penelitian seperti data RPJMD, Perda, dll.

\section{Teknik Pengumpulan Data}

Teknik pengumpulan data adalah cara peneliti untuk mengumpulkan data, dalam penelitian diperlukan teknik pengumpulan data karena dapat memperoleh sesuai yang diharapkan untuk menyelesaikan penelitian ini. Adapun teknik yang dipakai dalam penelitian ini, sebagai berikut:

\section{Wawancara}

Wawancara adalah pertemuan dua orang untuk bertukar informasi dan ide melalui tanya jawab sehingga dapat dikonstruksikan makna dalam suatu topik dan peneliti ingin mengetahui secara mendalam melalui responden yang ditanya (Sugiyono, 2008:72). Wawancara ini menggunakan wawancara semistruktur dimana pelaksanaannya lebih bebas dengan tujuan untuk menemukan permasalahan secara terbuka, dimana pihak yang diajak wawancara diminta pendapatnya dan ideidenya tentang Implementasi Observasi

Observasi merupakan suatu teknik pengumpulan data yang dilakukan oleh peneliti dengan mengamati peristiwa di lapangan. Peneliti menggunakan jenis observasi tak berstruktur dengan alasan agar peneliti dapat melakukan penelitian secara bebas, mencatat apa yang menarik, menganalisis kemudian menyimpulkan.

2. Dokumentasi

Pengumpulan data dengan memperoleh dokumen atau arsip dari instansi yang menjadi obyek penelitian. Data yang diperoleh adalah data yang berhubungan dengan permasalahan penelitian yang termasuk juga data yang berasal dari Internet, brosur, peraturan-peraturan, dan sejenisnya yang berhubungan dengan kebutuhan penelitian.

\section{Instrumen Penelitian}

Pada prinsipnya meneliti merupakan kegiatan untuk melakukan pengukuran maka harus terdapat alat ukur yang baik.Alat ukur dalam penelitian biasa disebut instrument penelitian. Instrumen penelitian dalam penelitian ini menggunakan:

\section{Peneliti Sendiri}

Metode penelitian yang digunakan yaitu penelitian kualitatif, dimana pengumpulan data lebih tergantung pada peneliti sendiri. Peneliti sebagai instrument utama dengan menggunakan panca indra untuk menyaksikan dan mengamati objek atau fenomena dalam penelitian ini.

2. Pedoman wawancara

Merupakan serangkaian pertanyaan yang diajukan kepada informan agar dapat terarah pada obyek yang dibutuhkan dalam penelitian.

3. Perangkat Penunjang

Yaitu alat yang perlukan peneliti untuk mencatat apa yang didengar, dilihat, dialami, dan dipikir dalam pengumpulan data di lapangan. Alat ini berupa buku catatan, alat tulis, kamera. Dan Handphone Sebagai alat bantu merekam hasil wawancara dan kamera sebagai alat bantu untuk mendokumentasikan secara visual kejadian di lapangan.

\section{Metode Analisis Data}

Analisis data yang digunakan dalam penelitian kualitatif dilakukan pada saat pengumpulan data berlangsung, dan setelah selesai mengumpulkan data dalam periode tertentu.Teknik yang digunakan untuk menganalisis data dalam penelitian ini adalah teknik deskriptif atau lebih spesifik menggunakan metode interaktif. Menurut Sugiyono (2008: 244), “analisis data adalah proses mencari dan menyusun secara sitematis data yang diperoleh dari hasil wawancara, catatan lapangan, dan bahan-bahan lain sehingga dapat dengan mudah dipahami, dan tentunya dapat diinformasikan kepada orang lain."

Model analisis data yang digunakan peneliti adalah model interaktif Miles, Huberman, dan Saldana (2014: 1214). Komponen dalam analisis data Miles, Huberman dan Saldana (2014: 12-13) sebagai berikut: 


\section{Kondensasi data (data condensation)}

Kondensasi data merujuk pada proses pemilihan, memfokuskan, menyederhanakan, mengabstraksikan, dan mentransformasikan data yang mendekati keseluruhan bagian dari catatan lapangan secara tertulis, transkrip wawancara, dokumen-dokumen dan materi-materi empiris. Kesimpulannya bahwa proses kondensasi data ini diperoleh setelah peneliti melakukan wawancara dan mendapatkan data tertulis yang ada di lapangan, yang nantinya traskrip wawancara tersebut dipilah-pilah untuk mendapatkan fokus penelitian yang dibutuhkan oleh peneliti.

2. Penyajian Data (data display)

Penyajian data merupakan sebuah pengorganisasian, penyatuan, dan informasi yang disimpulkan.Penyajian data disini juga membantu dalam memahami konteks penelitian karena melakukan analisis yang lebih mendalam.

3. Penarikan Kesimpulan (Conclusions drawing)

Penarikan kesimpulan disini dilakukan peneliti dari awal peneliti mengumpulkan data seperti mencari pemahaman yang tidak memiliki pola, mencatat keteraturan penjelasan, dan alur sebab akibat, yang tahap akhirnya disimpulkan keseluruhan data yang diperoleh peneliti.

Dari penjelasan di atas dapat ditarik kesimpulan bahwa dalam penelitian kualitatif merupakan temuan yang baru, dalam pengertian lain lain temuan tersebut masih bersifat samar-samar atau kurang jelas. Disini peneliti berusaha memperjelas dengan menggunakan teori yang sudah teruji keberhasilannya, lalu peneliti menganalisis temuan baru tersebut sehingga menjadi jelas dengan menggunakan komponen dari analisis data yaitu Kondensasi data (data condensation),Penyajian Data (data display), Penarikan Kesimpulan (Conclusion Drawing).”..

\section{HASIL DAN PEMBAHASAN}

Kota Malang berkomitmen dalam menerapkan kota berbasis Smart City, konsep smart city adalah kota cerdas/pintar yang membantu masyarakat yang ada di dalamnya dengan mengelola sumber daya yang ada dengan efisien dan memberikan informasi yang tepat kepada masyarakat/lembaga dalam melakukan kegiatannya ataupun mengantisipasi kejadian yang tak terduga sebelumnya.

Pemerintah Kota Malang melakukan beberapa strategi dalam meningkatan kualitas pelayanan publik berbasis konsep smart city antara lain dengan beberapa strategi. Yaitu:

(1) Strategi membangun (political environment) yang mendukung terselenggaranya tata kelola pemerintah kota Malang yang lebih melayani. Membangun lingkungan politik di sini termasuk di dalamnya mengeluarkan kebijakan-kebijakan publik yang mendukung terselenggaranya proses peningkatan pelayanan publik. Komitmen politik ini diawali dari Walikota Malang sebagai pemimpin tertinggi di daerah yang bereperan sebagai kunci pejabat publik yang memiliki visi dan misi membangun daerah Kota Malang.

Dalam sebuah wawancara dengan salah satu staf di pemerintah kota malang mengungkapkan bahwa pemerintah Kota Malang sangat berkomitmen dalam menerapkan electronic government, bahkan sejak era kepemimpinan Bapak Drs. Peni Suparto, M.AP Kota Malang sudah mulai dengan serius untuk menerapkan kebijakan tersebut. Bahkan pemerintah Kota Malang pernah mendapatkan penghargaan e-government award dari pemerintah pusat pada era kepemimpinannya.

Saat ini penerapan electronic government bahkan sudah diterapkan dalam tingkat Rukun Tetangga (RT), masyarakat dapat mengurus beberapa jenis surat atau dokumen kependudukan melalui perangkat handphone mereka.

Berbagai terobosan tersebut bertujuan memberikan kemudahan dan kenyaman bagi seluruh masyarakat atau penduduk kota malang. Wujud lain dari penerapan egovernment di malang adalah adanya sarana interaksi antara masyarakat dengan pihak pemerintah melalui piranti elektronik yaitu e-complaint dan complain warga melalui sms. Dengan adanya media yang berfungsi menyalurkan aspirasi masyarakat tersebut warga kota malang dapat menyampaikan berbagai keluhan tentang persoalan dalam proses pembangunan, pelayanan publik seperti pendidikan, kesehatan, infrastruktur dan lain sebagainya.

Pada era kepemimpinan bapak Mohammad Anton atau yang dikenal dengan sebutan Abah Anton, beliau sudah menerapkan kebijakan terkait e-government melalui program e-tax. Dalam program e-tax ini pemerintah Kota Malang dapat dengan lebih mudah melakukan penarikan pajak melalui wajib pajak melalui piranti elektronik. Hal ini memiliki beberapa manfaat, dari sisi wajib pajak dengan adanya fasilitas e-tax ini mempermudah wajib pajak untuk membayar pajak, salain itu dari aspek waktu yang dibutuhkan untuk mengurus pembayaran menjadi jauh lebih singkat karena secara otomatis pajak bisa dibayarkan kepemerintah daerah melalui sarana elektronik. Dari pihak pemerintah manfaat yang diperoleh adalah bahwa dengan adanya kebijakan ini peluang terjadinya kebocoran dana yang diperoleh dari sektor pajak bisa lebih dikurangi bahkan memungkinkan untuk dihilangkan.

(2) Strategi membangun teknologi yang mendukung terselenggaranya proses pelayanan publik yang berebasis pada perkembangan ilmu pengetahuan dan 
teknologi yang kini mengalami perkembangan yang sangat pesat. Membangun teknologi di sini berarti menyiapkan segala infrastruktur dalam rangka terselenggaranya electronic government termasuk di dalam nya menyiapkan sumber daya baik hardware, software maupun brainware.

Dalam strategi teknologi ini pemerintah sudah menyiapkan berbagai sarana infrastruktur pendukung untuk terlaksananya kebijakan electronik government. Pemerintah tidak mau tertinggal dari sektor bisnis (private) yang sudah lama menerapkan kegiatan atau aktifitas bisnis mereka menggunakan piranti elektronik. Sektor bisnis terbukti sukses menjalankan bisnis mereka dengan kehadiran teknologi tersebut. Dengan adanya fasilitas mengakses berbagai layanan melalui teknoli informasi seperti melalui aplikasi media sosial yang terinstal di masing-masing mobil phone mereka, masyarakat semakin tidak lagi masal adan merasa susah untuk mengurus dokumen administrasi kependudukan.

(3) Strategi menyiapakan dukungan anggaran untuk terselenggaranya program tersebut. Dukungan anggaran sangat vital bagi terselenggaranya kegiatan pelayanan publik. Dukungan anggaran ini perlu disiapkan sejak masa penyusunan Rencana Pembangunan Jangka Panjang dan Menengah Daerah (RPJPD dan RPJMD). Perlu kesepakatan bersama antarda eksekutif bersama legislatif daerah untuk mengesahkan dokumen perencanaan daerah tersebut.

Memang menjadi persoalan ketika anggaran daerah lebih banyak teralokasikan pada biaya rutin, seperti gaji pegawai, anggaran pembiayaan kendaraan dinas dll. Namun tanpa adanya dukungan anggaran yang jelas maka kebijakan ataupun program pengembangan e-government sulit terlaksanakan.

Dalam salah satu wawancara dengan salah satu staf di dinas komunikasi dan informasi pemerintah kota malang (dulu bernama Kantor Pengolah Data Elektronik). Menyatakan tentang masalah anggaran bahwa kebutuhan dana dalam pengadaan piranti elektronik government sangat besar, namun pemerintah Kota Malang masih berkomitmen penuh untuk melaksanakan electronik government karena dengan memberikan dukungan anggaran yang cukup diharapkan kebijakan ini berdampak pada peningkatan kualitas pelayanan publik.

(4) Strategi partisipasi seluruh stakeholders dalam mendukung terlaksananya program tersebut. Stakeholders di sini bisa berasal dari masyarakat, maupun dunia usaha (private sector), tanpa partisipasi dari seluruh stakeholders tersebut kebijakan yang bagus sekalipun akan terasa kurang berdampak pada perubahan positif yang merupakan dampak (outcome) dari sebuah kebijakan yang dihasilkan oleh (policy maker).
Dalam salah satu hasil wawancara dengan tokoh masyarakat terhadap penerapan elektronik government di malang dinyatakan bahwa masyarakat pada dasarnya sangat mendukung terlaksananya kebijakan e-government dalam bentuk smart city tersebut. Namun masyarakat sangat berharap bahwa pelaksanaan program tersebut dapat dijamin keberlanjutannya (sustainability). Hal ini dirasa penting oleh masyarakat karena seringkali yang dirasakan oleh masaryakat kebijakan kebijakan yang bagus di lapangan kadang hanya bersifat meraih citra positif tanpa keseriusan yang penuh atau political will yang memadai dari para elit pembuat kebijakan

\section{PENUTUP}

\section{Simpulan}

Kesimpulan dari penelitian ini adalah pemerintah Kota Malang telah melakukan beberapa strategi dalam membangun pelayanan publik berbasis smart city dengan beberapa strategi antara lain yaitu dengan strategi membangun lingkungan politik, strategi membangun teknologi pendukung, strategi menyiapkan anggaran dan strategi mendorong partisipasi masyarakat.

\section{Saran}

Adapun saran dari penelitian ini adalah perlunya menjadi keberlanjutan (sustainbility) agar program yang sudah baik berjalan bisa terus dirasakan manfaatnya oleh masyarakat.

\section{DAFTAR PUSTAKA}

Indradi, S. 2006. Dasar-dasar dan teori administrasi publik. Malang: Agritek YPN

Indrajit, Richardus Eko (2004). E-Government Strategi Pembangunan Dan Pengembangan Sistem Pelayanan Publik Berbasis Teknologi Digital. Yogyakarta:Andi Offset.

Nawawi, Ismail. 2009. Public Policy (Analisis, Strategi Advokasi Teori dan Praktek). Surabaya: Penerbit PMN

Saldana., Miles \& Huberman. 2014. Qualitative Data Analysis. America: SAGE Publications

Subarsono, A.G. 2012. Analisis Kebijakan Publik: Konsep, Teori, dan Aplikasi. Yogyakarta: Pustaka Pelajar.

Sugiyono. 2008. Memahami Penelitian Kualitatif. Bandung: cv. Alfabeta. 